\title{
PENERAPAN METODE COURSE REVIEW HORAY UNTUK MENINGKATKAN MINAT DAN HASIL BELAJAR MAHASISWA PRODI PENDIDIKAN BIOLOGI UNIVERSITAS BENGKULU
}

\section{The Use of Course Review Horay Method to Increase Students Interest and Learning Results in Biology Education Department in Universitas Bengkulu}

\author{
Nike Anggraini, Irwandi Ansori, Rendi Zulni Eka Putri \\ Prodi Pendidikan Biologi JP MIPA FKIP Universitas Bengkulu, Bengkulu, \\ Indonesia \\ email: ike.anggraini.nike@gmail.com
}

\begin{abstract}
The Purpose of this study is to determine the use of Course Review Horay method for increasing students interest in Vertebrate Zoology courses in Biology Education Department year 2017/2018. This study is a Classroom Action Research, the subjects consisted of 47 students. Data were collected using observation, questionnaires, and documentation. Data obtained were analyzed using descriptive analysis and effect size. This study was conducted in three cycles, each consisting of one meeting during $2 \times 50$ minutes. Result showed that the Course review horay method could increase students' interest and the cognitive learning outcomes. Based on questionnaires on students learning interest, at cycle I, data obtained as much as $44,73 \%$, while at cycle II showed an increase in average score by $81,58 \%$. As for the cognitive learning outcomes showed an increase in post-test value in each cycle. The effect size between cycle I and cycle II as much as 0.39 representing small effect size. While the effect size for cycle II and III were 1, 78 which represent high effect size.
\end{abstract}

Keywords: Course review horay method, students interest, learning results. 


\section{PENDAHULUAN}

Sejalan dengan perkembangan paradigma dunia tentang makna pendidikan bahwa diharapkan ada tantangan yang semakin berat. Salah satu tantangan nyata tersebut adalah bahwa pendidikan hendaknya mampu menghasilkan sumber daya manusia yang memiliki kompetensi utuh. Kompetensi yang diharapkan yang dimiliki sumber daya manusia saat ini lebih dititikberatkan pada kompetensi berpikir dan komunikasi. (Hanafiah, 2010). Untuk mencapai kompetensi diatas terus dilakukan pembaharuan-pembaharuan oleh lembaga pendidikan tinggi kependidikan (LPTK) melalui program-program yang dikoordinasikan oleh Direktorat Jendral Pendidikan Tinggi, antara lain melalui program hibah penelitian (PIPS), Hibah pengajaran (PPKP) yang dilakukan oleh FKIP Universitas Bengkulu.

Banyak faktor yang berpengaruh terhadap proses pembelajaran mahasiswa (calon guru) baik secara eksternal maupun internal. Faktor-faktor eksternal mencakup dosen, materi perkuliahan, pola interaksi, media dan teknologi, situasi belajar, dan sistem penilaian atau asesmen. Masih ada dosen yang dominan menggunakan metode ceramah dalam perkuliahannya, dan dalam mengevaluasi mahasiswa dituntut jawaban yang persis sama seperti yang ia jelaskan, sehingga mahasiswa tidak memiliki peluang untuk berpikir kreatif. Metode pembelajaran adalah teknik penyajian yang dikuasai oleh guru untuk mengajar atau menyajikan bahan pelajaran pada siswa di dalam kelas, baik secara individual maupun secara kelompok (Pasaribu, 2003). Hal ini mendorong seorang guru harus mencari metode yang tepat dalam penyampaian materi agar dapat diserap baik oleh siswa. Mengajar secara efektif sangat bergantung pada pemilihan dan penggunaan metode mengajar.

Pelaksanaan perkuliahan di Prodi Pendidikan Biologi dapat dikatakan cukup baik karena perkuliahan dilakukan oleh dosen melalui berbagai metode dan strategi pembelajaran meskipun belum inovatif. Salah satu metode pembelajaran yang banyak digunakan oleh dosen adalah metode konvensional. Metode ini ditandai dengan ceramah yang diiringi penjelasan, serta pembagian tugas dan latihan (Pasaribu, 2003). Metode ini 
memiliki kekurangan yaitu menyebabkan mahasiswa pasif dalam proses pembelajaran, karena hanya dituntut untuk mendengarkan penjelasan dosen dan mahasiswa merasa bosan sehingga menyebabkan berkurangnya minat belajar siswa (Vembrianto, 1985).

Metode konvensional sangat tidak cocok digunakan pada mata kuliah dengan materi yang cakupannya luas, karena pada semester tahun ajaran yang lalu masih ditemukan mahasiswa yang memperoleh hasil belajar di bawah ketuntasan klasikal individu yang sudah ditentukan tim dosen yakni $\geq 70$ serta dinyatakan tuntas secara klasikal apabila mahasiswa di kelas memperoleh nilai $\geq$ sebanyak 85\%. Berdasarkan hasil diskusi tim dosen yang mengampu mata kuliah Zoologi Vertebrata akhirnya menyimpulkan perlu dicari alternatif perkuliahan yang memberikan kesempatan mahasiswa untuk dapat terlibat aktif dan menarik bagi mahasiswa dalam pembelajaran. Salah satu langkah yang dapat diakukan yakni dengan menerapkan metode Course review horay.

\section{METODE PENELITIAN}

Jenis penelitian adalah Penelitian Tindakan Kelas (Classroom Action Research). Jenis penelitian ini merupakan penelitian yang bertujuan untuk mengatasi masalah pembelajaran atau perbaikan pembelajaran dan peningkatan kualitas pembelajaran relevan bagi guru dan dosen sebagai peneliti (Teacher as Research), dan memiliki keunggulan, dapat memperbaiki kualitas pembelajaran yang dilakukannya. Menurut Hopkins dalam Rochiati Wiriaatmadja (2006). Penelitian Tindakan Kelas mengkombinasikan prosedur penelitian dengan tindakan subtantif dengan adanya perbaikan terus-menerus sehingga tercapai sasaran dari penelitian tersebut. Subyek Penelitian adalah mahasiswa Pendidikan Biologi Semester III Jurusan PMIPA Program Studi Pendidikan Biologi FKIP UNIB Tahun Ajaran 2017/2018 yang mengikuti perkuliahan Zoologi Vertebrata.

\section{A. Subjek Penelitian}

Subyek Penelitian adalah mahasiswa Pendidikan Biologi Semester III Jurusan PMIPA Program Studi Pendidikan Biologi 
FKIP UNIB Tahun Ajaran 2017/2018 yang mengikuti perkuliahan Zoologi Vertebrata.

\section{B. Prosedur Penelitian}

Penelitian ini dilakukan persiklus yang tiap siklusnya mencakup tiga tahapan, (1) Tahap Perencanaan, (2) Tahap Pelaksanaan Tindakan dan observasi serta evaluasi, dan (3) Tahap Refleksi (Hopkins, 1993).

\section{Teknik Analisa Data}

Teknik analisa data yang digunakan dalam penelitian ini adalah adalah analisis deskriptif kuantitatif yaitu suatu penelitian yang ditujukan untuk mendeskripsikan fenomena-fenomena yang mengkaji bentuk, aktivitas, karakteristik, perubahan, hubungan dan yang lainnya (Sukmadinata, 2011).

1) Hasil angket, dianalisis menggunakan Skala Likert yang mempunyai gradasi dari sangat positif sampai sangat negatif berupa kata-kata antara lain: Sangat tidak setuju, tidak setuju, raguragu, setuju dan sangat setuju. Skor untuk butir pernyataan yang sifatnya positif yaitu: Sangat Setuju (5), setuju (4), Ragu-ragu (3), Tidak setuju (2), dan sangat tidak setuju (1). Sebaliknya untuk pernyataan yang bersifat negatif yaitu sangat setuju (1), setuju (2), ragu-ragu (3), tidak setuju (4), sangat tidak setuju (5). Penentuan kategori hasil pengukuran minat belajar mahasiswa pada mata kuliah Zoologi Vertebrata pada tabel berikut ini:

Tabel 1.

Penentuan kategori hasil pengukuran minat belajar mahasiswa

\begin{tabular}{|l|c|c|}
\hline No & Skor & Kategori Minat Belajar \\
\hline 1 & Lebih besar dari 80 & Sangat Tinggi \\
\hline 2 & 70 sampai 79 & Tinggi \\
\hline 3 & 50 sampai 69 & Rendah \\
\hline 4 & Kurang dari 50 & Sangat Rendah \\
\hline
\end{tabular}

Sumber: Wardani, dkk (2012)

2) Hasil tes, dianalisis dengan menggunakan nilai rata-rata dan kriteria ketuntasan belajar secara klasikal. Pembelajaran 
dikatakan tuntas secara klasikal, jika mahasiswa di dalam kelas memperoleh nilai $\geq 70$ sebanyak $85 \%$

a. Nilai rata-rata kelas dengan rumus; $\mathrm{X}=\sum \mathrm{X} / \mathrm{N}$

$\mathrm{X}=$ nilai rata-rata kelas

$\sum \mathrm{X}=$ Jumlah nilai siswa keseluruhan

$\mathrm{N}=$ Jumlah Seluruh Siswa

b. Ketuntasan Belajar dengan rumus

$(\mathrm{KB})=\mathrm{NS} / \mathrm{N} \times 100 \%$

$\mathrm{KB}=$ ketuntasan belajar mhs

NS = Jumlah mhs yg mendapat nilai $\geq 70$

$\mathrm{N}=$ Jumlah seluruh siswa

\section{Teknik Pengumpulan Data}

Data penelitian terdiri atas: (1) Data minat belajar mahasiswa Semester II mata kuliah Zoologi Vertebrata menggunakan metode Course Review Coray; (2) Data hasil belajar mahasiswa Semester III mata kuliah Zoologi Vertebrata menggunakan metode Course Review Coray

\section{Cara Pengumpulan data}

Data minat belajar: Pengumpulan data menggunakan lembar angket, Data hasil belajar: Pengumpulan data dengan menggunakan lembar test

\section{Perhitungan Effect Size}

Jika diperoleh hasil bahwa penggunaan metode course review horay memberikan pengaruh yang signifikan terhadap minat dan hasil belajar mahasiswa, maka selanjutnya dicari ukuran pengaruhnya (effect size). Menurut Olejnik dan Algina dalam Santoso (2010), effect size adalah ukuran mengenai besarnya efek suatu variabel lain, besarnya perbedaan maupun hubungan, yang bebas dari pengaruh besarnya sampel. Menghitung effect size menggunakan rumus Cohens'd sebagai berikut: 


$$
d=\frac{x 1-x 2}{\text { Spooted }}
$$

Dengan

$$
S_{\text {pooled }}=\frac{\overline{n_{\mathrm{t}}=1 s_{\mathrm{t}}^{2}+\left(n_{\mathrm{t}}-1\right) s_{\mathrm{k}}^{2}}}{n_{\mathrm{t}}+n_{\mathrm{c}}}
$$

Keterangan:

$\begin{array}{ll}\text { Spooted } & \text { : Standar deviasi gabungan } \\ n_{i} & \text { : Jumlah sampel kelas eksperimen } \\ n_{c} & \text { : Jumlah sampel kelas control } \\ S_{t} & \text { :Standar deviasi kelaseksperimen } \\ S_{c} & \text { : Standar deviasi kelas kontrol }\end{array}$

Harga $d$ menggambarkan besarnya pengaruh variabel bebas yang diintervensikan pada kelompok percobaan pada suatu variabelterikat. Kriteria besarnya Effect Size diklasifikasikan sebagai berikut:

$$
\begin{array}{ll}
d<0,2 & \text { : Kecil } \\
0,2<d<0,8 & \text { : Sedang } \\
\quad d>0,8 & \text { : Besar }
\end{array}
$$

\section{HASIL DAN PEMBAHASAN}

Sebelum melakukan tindakan dengan menggunakan model $\mathrm{CRH}$, langkah awal yang dilakukan adalah melakukan observasi terhadap mahasiswa semester III dalam proses pembelajaran dengan menggunakan metode ceramah pada materi sebelumnya. Setelah itu, peneliti memberikan tes kepada siswa untuk melihat seberapa besar hasil belajar siswa. Dari 47 siswa yang mengikuti tes awal, 29 orang mahasiswa dinyatakan belum tuntas atau belum mencapai Kriteria Ketuntasan Minimal (KKM) yang ditetapkan di tim dosen yakni $\geq 70$ serta dinyatakan tuntas secara klasikal apabila mahasiswa di kelas memperoleh nilai $\geq$ sebanyak $85 \%$. Hasil tes siswa pada tahap pra tindakan dapat dilihat pada tabel 2 . 
Tabel 2.

Hasil Analisis Tes Pra Tindakan

\begin{tabular}{|l|l|c|}
\hline No & \multicolumn{1}{|c|}{ Aspek Perolehan } & Hasil \\
\hline 1. & Skor Tertinggi & 82,7 (3 orang) \\
\hline 2. & Skor Terendah & 32 (1 orang) \\
\hline 3. & Nilai Rata-Rata & 58,70 \\
\hline 4. & Banyak siswa yang tuntas & 18 orang \\
\hline 5. & $\begin{array}{l}\text { Persentase ketuntasan belajar } \\
\text { klasikal }\end{array}$ & $38,3 \%$ \\
\hline
\end{tabular}

Berdasarkan hasil tes pra tindakan, peneliti (tim dosen) membicarakan hasil pengamatan yang didapatkan dan kemudian membicarakan rencana perbaikan tindakan pembelajaran. Tindakan ini di rencanakan terdiri dari 2 (dua) siklus, dan dalam setiap siklus terdiri dari dua kali pertemuan. Dalam pelaksanaannya peneliti bertindak sebagai Dosen dan anggota tim yang lain bertindak sebagai pengamat. Tahap perbaikan pembelajaran terdiri dari dua siklus, dan tiap siklus terdiri atas perencanaan, pelaksanaan, observasi, dan refleksi.

Setelah selesai pelaksanaan kegiatan pembelajaran tindakan siklus I dengan menggunakan model pembelajaran Course Review Horay, kegiatan selanjutnya adalah pemberian tes untuk mengetahui kemampuan masing-masing siswa. Bentuk tes kemampuan belajar yang diberikan adalah uraian tes dan hasil tes tindakan siklus I dapat dilihat pada Tabel 3.

\section{Tabel 3.}

Hasil Analisis Tes Siklus I

\begin{tabular}{|l|l|c|}
\hline No & \multicolumn{1}{|c|}{ Aspek Perolehan } & Hasil \\
\hline 1. & Skor Tertinggi & 84 (3 orang) \\
\hline 2. & Skor Terendah & $50(2$ orang) \\
\hline 3. & Nilai Rata-Rata & 64,75 \\
\hline 4. & Banyak siswa yang tuntas & 26 orang \\
\hline 5. & Persentase ketuntasan belajar klasikal & 55,31 \\
\hline
\end{tabular}


Ketuntasan belajar klasikal pada siklus I sebesar 55,31\%. Hasil analisis tes akhir siklus I ini memperlihatkan bahwa hasil belajar mahasiswa belum sesuai dengan standar Kriteria Ketuntasan Minimal yakni bahwa suatu kelas dikatakan tuntas belajar secara klasikal jika rata-rata $70 \%$ siswa telah tuntas secara individual. Dengan demikian dapat disimpulkan bahwa hasil kegiatan pembelajaran siklus I belum berhasil. Pelaksanaan siklus II tidak jauh berbeda dengan pelaksanaan siklus I, hanya saja beberapa hal yang dianggap kurang pada siklus I akan diperbaiki pada siklus II dan disesuaikan dengan perubahan yang ingin dicapai. Hasil observasi aktivitas siswa di siklus II diperoleh persentase nilai rata-rata sebesar $85,10 \%$.

Setelah selesai pelaksanaan kegiatan pembelajaran tindakan siklus II dengan menggunakan model pembelajaran Course Review Horay, kegiatan selanjutnya adalah pemberian tes untuk mengetahui kemampuan akhir masing-masing siswa. Bentuk tes kemampuan belajar yang diberikan adalah uraian tes, dan hasil tes tindakan siklus III dapat dilihat pada Tabel 4 .

Tabel 4.

Hasil Analisis Tes Siklus II

\begin{tabular}{|l|l|c|}
\hline No & \multicolumn{1}{|c|}{ Aspek Perolehan } & Hasil \\
\hline 1. & Skor Tertinggi & $92(8$ orang) \\
\hline 2. & Skor Terendah & $68(5$ orang) \\
\hline 3. & Nilai Rata-Rata & 86,70 \\
\hline 4. & Banyak siswa yang tuntas & 40 orang \\
\hline 5. & Persentase ketuntasan belajar klasikal & 85,10 \\
\hline
\end{tabular}

Hasil evaluasi pembelajaran siklus II menunjukkan, bahwa kemampuan mahasiswa Pendidikan Biologi Universitas Bengkulu sudah menunjukkan hasil yang baik dengan nilai rata-rata siswa mencapai 86, 70 ketuntasan belajar klasikal 85\% Hasil ini memberi penjelasan bahwa pembelajaran yang dilaksanakan di dalam kelas sudah memperoleh hasil yang diinginkan walaupun masih terdapat 
7 orang mahasiswa yang belum tuntas dalam pembelajarannya. Dengan demikian dapat disimpulkan bahwa hasil kegiatan pembelajaran siklus II sudah berhasil. Hasil tersebut sudah memenuhi indikator kinerja yang dipersyaratkan berdasarkan Kriteria Ketuntasan Minimal (KKM) yaitu dikatakan tuntas belajar secara klasikal jika rata-rata $70 \%$ siswa telah tuntas secara individual.

Tindakan penelitian dengan menggunakan metode CRH dalam pembelajaran dilakukan dalam dua siklus. Ketuntasan belajar klasikal pada siklus I sebesar 55,31 \% dengan minat sebelajar 44, $73 \%$. Hasil analisis tes akhir siklus I ini memperlihatkan bahwa hasil belajar maupun minat belajar mahasiswa belum sesuai dengan standar Kriteria Ketuntasan Minimal yakni bahwa suatu kelas dikatakan tuntas belajar secara klasikal jika rata-rata 70\% siswa telah tuntas secara individual. Sehingga perlu dilaksanakan siklus II. Hasil observasi aktivitas siswa memperoleh presentase sebesar $61,36 \%$ atau berada pada kategori cukup. Sedangkan hasil observasi aktivitas guru memperoleh presentase sebesar 86,11\% atau berada pada gategori baik. Hal ini memperlihatkan bahwa selama proses pembelajaran, siswa maupun guru berupaya menciptakan suasana pembelajaran yang baik sesuai dengan yang diharapkan berdasarkan model pembelajaran yang diterapkan.

Peningkatan hasil belajar siswa juga terlihat pada siklus II. Evaluasi pembelajaran siklus II menunjukkan, bahwa kemampuan mahasiswa sudah menunjukkan hasil yang baik dengan ketuntasan belajar klasikal mencapai 85,10 \%, dengan persentase minat belajar mencapai 81,58\%. Hasil ini memberi penjelasan bahwa pembelajaran yang dilaksanakan di dalam kelas sudah memperoleh hasil yang diinginkan walaupun masih terdapat 7 orang mahasiswa yang belum tuntas dalam pembelajarannya. Dengan demikian dapat disimpulkan bahwa hasil kegiatan pembelajaran siklus II sudah berhasil. Hasil tersebut sudah memenuhi indikator kinerja yang dipersyaratkan berdasarkan Kriteria Ketuntasan Minimal (KKM) yaitu jika suatu kelas dikatakan tuntas belajar secara klasikal jika rata-rata 70\% siswa telah tuntas secara individual. Peningkatan hasil belajar ini juga didukung oleh meningkatnya aktivitas siswa dan guru dalam proses pembelajaran. Aktivitas siswa berada pada kategori sangat baik 
dengan nilai 90,90\%, begitu pula aktivitas guru berada pada kategori sangat baik dengan nilai 97,22\%.

Meningkatnya hasil belajar dan aktivitas siswa ini dikarenakan dosen telah menerapkan metode lain selain ceramah dalam pembelajaran. Unsur metode dan alat merupakan unsur yang tidak bisa dilepaskan dari unsur lainnya yang berfungsi sebagai cara atau teknik untuk mengantarkan bahan pelajaran agar sampai kepada tujuan. Metode pembelajaran sangat penting, sebab dengan adanya metode pembelajaran bahan ajar dapat dengan mudah dipahami oleh siswa. Penggunaan metode dalam pembelajaran sangat diutamakan guna menimbulkan gairah belajar, motivasi belajar, merangsang siswa berperan aktif dalam proses pembelajaran. Melalui metode pembelajaran diharapkan dapat lebih mempermudah pemahaman materi pelajaran yang diberikan dan nantinya dapat mempertinggi kualitas proses pembelajaran yang selanjutnya dapat meningkatkan hasil belajar siswa. (Sugiyono, 2012).

Penggunaan model pembelajaran Course Review Horay dalam pembelajaran sangat baik karena memiliki Keunggulankeunggulan yaitu meningkatkan keaktifan siswa dalam belajar, menciptakan suasana belajar yang menyenangkan sehingga siswa tidak mudah bosan dalam belajar, dan mempererat hubungan sosial antar siswa karena siswa harus mengucapkan selamat kepada temannya yang berhasil menjawab soal secara vertikal, horisontal, atau diagonal dengan benar. Pada model pembelajaran Course Review Horay aktivitas belajar lebih banyak berpusat pada siswa. Dalam hal ini pada proses pembelajaran guru hanya bertindak sebagai penyampai informasi, fasilitator, dan pembimbing. Suasana belajar dan interaksi yang menyenangkan membuat siswa lebih menikmati pelajaran sehingga siswa tidak mudah bosan untuk belajar. Hal ini dapat memupuk minat dan perhatian siswa dalam mempelajari IPA, yang pada akhirnya dapat berpengaruh terhadap hasil belajar siswa. (Pratiwi, 2011).

Uji efektifitas dilakukan guna mengetahui penggunaan metode course review horay dalam meningkatkan hasil dan minat belajar mahasiswa. Perhitungan effect size pada penelitian ini dilakukan secara manual. Adapun hasil perhitungan effect size antara siklus I dan siklus II sebesar 0,39 sehingga masuk dalam kategori kecil. 
Sementara effect size untuk siklus II dan III yakni sebesar 1, 78 sehingga masuk dalam kategori efek besar.

\section{KESIMPULAN}

Melalui penerapan model Course Review Horay pada mata kuliah Zoologi Vertebrata, Program Studi Pendidikan Biologi, Universitas Bengkulu dapat meningkatkan minat dan hasil belajar mahasiswa selama proses pembelajaran Untuk peningkatan minat belajar siswa dapat dilihat dari peningkatan setiap aspek pengamatan. hal ini dikarenakan aktivitas dosen yang lebih membimbing mahasiswa dalam pembelajaran sehingga mahasiswa dapat aktif dan mampu melakukan kegiatan tersebut dengan baik dan benar.

Perbaikan pembelajaran melalui Course Review Horay pada mata kuliah Zoologi Vertebrata, Program Studi Pendidikan Biologi, Universitas Bengkulu dapat meningkatan hasil belajar. Hal ini terlihat pada siklus I hasil belajar mahasiswa dengan kriteria belum tuntas meningkat pada siklus II dengan kriteria tuntas.

\section{DAFTAR PUSTAKA}

Hanafiah dan Suhana, C. (2010). Konsep Strategi Pembelajaran. Bandung: PT Refika Aditama.

Kusumarini, E. (2012). Model Pembelajaran Course Review Horay. [Online]. Tersedia:http://rinkuchiki.blogspot.com/ 2012/06/model-pembelajaran-course-review-horay.html [14 Agustus 2014].

Pasaribu, I.L dan Simanjuntak. 2003. Proses Belajar Mengajar. Bandung: Tarsito

Pratiwi, L. (2011). Penerapan Model Course Review Horay (CRH) Untuk Meningkatkan Pembelajaran IPA Siswa Kelas IV SDN Merjosari 1 Malang. [Online]. Tersedia: http: //library.um.ac.id/ptk/index.php?mod=det ail \&id=49001 [27 Oktober 2014]. 
Penerapan Metode Course Review Horay...

Sugiyono. (2007). Metode Penelitian Pendidikan. Bandung: Alfabeta.

Sukmadinata, N. (2011). Metode Penelitian Pendidikan. Bandung: Remaja Rosdakarya.

Vembrianto, 1985. Pengantar Pengajaran Modul. Yogyakarta: Yayasan Pendidikan Paramita 